\title{
Placenta functions with special emphasis on endocrine changes - a comparative overview Hans Kindahl
}

\begin{abstract}
Address: Department of Clinical Sciences, Swedish University of Agricultural Sciences, Uppsala, SE-750 07 Uppsala, Sweden
\end{abstract} Email: Hans Kindahl - hans.kindahl@kv.slu.se

from Perinatal Death In Domestic Animals: The 20th Symposium of the Nordic Committee for Veterinary Scientific Cooperation (NKVet) Reykjavik, Iceland. 26-27 April 2007

Published: 12 December 2007

Acta Veterinaria Scandinavica 2007, 49(SuppI I):SI5 doi:I0.II86/I75I-0I47-49-SI-SI5

This abstract is available from: http://www.actavetscand.com/content/49/SI/SI5

(c) 2007 Kindahl; licensee BioMed Central Ltd.

The placenta is literally a "sac" covering and allowing the foetus to be nourished and developed until the process of parturition. Trophoblastic cells are part of/responsible for the "maternal recognition of pregnancy" as well as initiation of parturition. After parturition this temporary organ should be expelled as soon as possible. There are many intrinsic factors involved in all these processes to bring the conceptus/foetus to a successful end and also guarantee that the newborn can manage the first time of postnatal life.

One realistic question is how the hormones are fluctuating during pregnancy and if the changes can give us any information of the process of foetal maturation or the socalled "foetal well-being". One hormone in common for all species is progesterone, the well-known gestagen promoting the gestation. Changes of progesterone appear also during the luteal phase of the oestrous cycle produced from the corpus luteum. The hormone was first purified from the corpus luteum and Fraenkel et al. [1] demonstrated that corpora lutea were necessary for implantation and the subsequent maintenance of pregnancy in the rabbit. Slotta et al. [2] named the compound progesterone and suggested a structural formula. After asuccessful maternal recognition of pregnancy the corpus luteum continues to produce progesterone until term in the cow, sow, doe, bitch and queen. However the cow has also a major contribution from the placenta and maybe also from the maternal adrenals. The latter production sites are known as the "extra-ovarian sources". The main production from the placenta is during the period of 5-7 months of pregnancy and it is not understood why this production appears since it is not that the placenta permanently takes over the progesterone production. The production as such is most annoying in attempts to abort pregnant cows in this period - all efforts seem to be unsuccessful and cause harm to the animals! The production from the placenta diminishes during the last months of pregnancy and the pregnancy is again solely dependent on progesterone production from the corpus luteum. As a result, the initiation of parturition might be easier since a lower amount of the luteolytic substance - prostaglandin $\mathrm{F}_{2 \alpha}$ - is needed to cause luteolysis of the corpus luteum resulting in low progesterone levels than that the tight connections of the cotyledonary placenta should be loosened by the smooth contracting substance - prostaglandin $\mathrm{F}_{2 \alpha}$ - and cause the drop of progesterone! The ovine and equine species both demonstrate a similar endocrine situation in that the role of the corpus luteum is overtaken by the placenta - in the ewe it seems to be progesterone in both cases, but in the mare the placenta is producing $5 \alpha$-pregnane instead of progesterone [3]. However many immunoassay systems recall the $5 \alpha$-pregnane as progesterone or part of it due to cross-reaction in different magnitudes of the antisera. The literature is as a result demonstrating a variety of progesterone profiles in the pregnant mare. The mare is also unique in its capacity to produce progesterone from the secondary corpora lutea. Both the ewe and mare produce large amounts of prostaglandin $\mathrm{F}_{2 \alpha}$ at the time of parturition most likely due to that the placenta must loose the contacts with the uterine wall to be able to decrease progesterone levels $[4,5]$. 
Since progesterone in most species is produced in the corpus luteum it is expected that only in the ewe and mare changes in the levels could indicate an impaired pregnancy and that the placenta function is disturbed. In the ewe this has been demonstrated in experimental situation exposing the pregnant ewes for e.g. Toxiplasma gondii organisms [6]. The progesterone production diminishes due to the insult (calcification in the placenta) and the result can be abortions, mummified foetuses, but the pregnancy can also end successfully in live born lambs.

In the cow many attempts have been done to use progesterone levels as an indicator of the pregnancy outcome or the status of the foetus (for a review, see [7]). The only information gained is if the foetus is still in the uterus or not, thus low progesterone levels during pregnancy indicate that the abortion process is more or less complete.

An alternative way to study the importance of progesterone is to use 'antiprogestins' e.g. progesterone receptor blockers such as aglepristone (RU 46534). Trade name is Alizine. This drug can be used to counteract the binding of progesterone to its receptor and thus pregnant animals will abort [8]. In cattle, progesterone levels are declining after the treatment, though the main source of production in late pregnant animals is from the corpus luteum. Obviously, a luteolytic uterine derived factor is involved in the decline of progesterone. In the dog, several studies have been performed to induce abortion [9-11] or parturition [12].

As already mentioned progesterone and prostaglandin $\mathrm{F}_{2 \alpha}$ seems to have interplay in many situations. Prostaglandin $\mathrm{F}_{2 \alpha}$ is responsible for luteolysis of the corpus luteum before parturition in the cow, doe, sow, bitch and queen and the same endocrine event (decrease of progesterone) is seen due to disruption of the foeto-maternal unit in the mare and ewe. A release is thus seen of prostaglandin $F_{2 \alpha}$ in all species, in most cases monitored as its main circulating metabolite 15-ketodihydroprostaglandin $\mathrm{F}_{2 \alpha}$ [13]. In both the ewe and mare the levels at the end of pregnancy (the last trimester) are certainly at such a high magnitude that corpus luteum should, if present, be luteolysed, but in these species the placenta maintains the progesterone/ $5 \alpha$-pregnane production $[4,5]$.

Prostaglandins seem to have several functions: they are produced in physiological situation causing luteolysis of the corpus luteum or disruption of the foeto-maternal contacts, but are also formed in inflammatory processes. The profiles of the prostaglandin metabolite have in many situations been used to judge if the pregnancy proceeds in a normal fashion or if something might go wrong. Examples of this are bovine virus diarrhoea virus in cattle [14] and sheep [15], Toxoplasma gondii in the ewe [6] and in several species exposure of endotoxins from Gram-negative bacteria (e.g. $[16,17])$.

Production of prostaglandins can be inhibited by nonsteroidal anti-inflammatory drugs (NSAIDs) such as aspirin, indomethacin, flunixin, ketoprofen, meloxicam. Several of these substances can be used in veterinary therapeutics, but they are also valuable tools in understanding the role of arachidonic acid metabolites in different processes. However it is important to know the degree of inhibition and not only think that a single use of an NSAID can totally diminish the importance of prostaglandins. As an example, to counteract the luteolytic synthesis of prostaglandin $\mathrm{F}_{2 \alpha}$ and to prevent luteolysis, flunixin meglumine has to be given four times daily in heifers [18]. The use of flunixin meglumine in cattle exposed to Gramnegative endotoxins can block the production and release of prostaglandins [19] and thus it is most likely that also pregnant cattle can be rescued with pretreatments of flunixin before endotoxins as is the case in e.g. the mare [20].

As demonstrated in the classical experiments of Liggins [21] one key enzyme in the process of initiation of parturition is $17 \alpha$-hydroxylase converting progesterone into free oestrogens (mainly oestrone). This enzyme has clearly been demonstrated in the ewe and cow, and most likely is present in several other species. The induction of this enzyme is due to an increased production of cortisol from the foetus (the process of readiness for birth). Cortisol seems to have dual roles at the end of pregnancy - first is the induction of $17 \alpha$-hydroxylase and the second is the cortisol induced lipocortin acting as a potent phospholipase inhibitor decreasing the amount of free arachidonic acid thus causing an inhibition of prostaglandin production [22].

Liggins et al.[21] demonstrated that the foetal pituitary and adrenal glands was the major pathway for the signals that initiated the birth process in sheep. The levels of cortisol in the maternal blood circulation are very high during the time of parturition [23]. These rising levels were reported to be related to the stress condition with labour $[24,25]$. Twin-bearing cows had significantly higher mean plasma cortisol levels on the day of parturition than the singleton cows [24]. In the same study, a single cow giving birth prematurely had $100 \%$ higher plasma cortisol levels on the day of parturition and one day postpartum than cows giving birth at term. Königsson et al. [26] reported that after dexamethasone-induced parturitions distinct peaks of cortisol were only seen in cows with retained foetal membranes. This might be due to some kind of stress due to prolonged or difficult calving as suggested by Hydbring et al. [25], but might also be due to an effect of the retained foetal membranes per se. Cows delivering the placenta at normal time did not have any peaks of cortisol 
[26]. Since cortisol is produced within the foeto-maternal unit and has to be transported to the maternal circulation, the circumstances around parturition may result in different degree of resorption (e.g. if the labour process is prolonged more cortisol is resorbed, if the placenta is delivered at expected time less cortisol is resorbed, etc).

A unique cell type is found in the ruminant foetal membranes. These cells are called binucleate giant cells, characterised by their morphology as being large and having two nuclei. They originate from trophoblastic cells and secrete proteins, which are specific to the foetal membranes and pregnancy in ruminants e.g, pregnancy specific protein B (PSPB) and pregnancy associated glycoproteins (PAG). The latter proteins are classified as probably inactive members of the aspartic proteinase family. Pepsinogen, renin, cathepsin E \& D and chymosine are typical members of this family [27]. These proteins are secreted in the peripheral blood of the pregnant female from early pregnancy through the end of gestation. Thus, they are useful for both pregnancy confirmation and monitoring of trophoblastic functions. They are also most likely present in the mare, but so far no assays are available to detect its presence. Porcine pregnancy-associated glycoprotein (pPAG) family is very "promiscuous" and its role(s) remains unknown [28]. It seems that chorionic pPAG family can be involved in luteoprotective mechanism during implantation and placentation, according to the binding-interaction with luteal and uterine gonadotropin receptors of pregnant pigs. In the near future we will probably know much more about the PAG superfamily in different species.

In a report by Zoli et al. [29], a bovine pregnancy associated glycoprotein (PAG) was purified from the foetal cotyledons. This protein could be detected in the maternal blood circulation at around the time when the trophoblast forms definitive attachment to the uterine wall. Afterwards, the levels increase gradually and a dramatic increase is recorded during the last 10 days prior to parturition. The peak value is found on days 1-5 prepartum, and after delivery the levels decline steadily. The relatively long time needed for the clearance of this protein from the maternal blood circulation is due to its high levels at the time of parturition and by a long specific half-life of this protein [30].

Kornmatitsuk et al. [31] analysed PAG in Holstein heifers sired by bulls with breeding values for a high risk of stillbirth (experimental group) and a low risk of stillbirth (control group; this group should perform better than the average heifer). The results of this study indicated two different backgrounds of stillbirth: stillbirth as a result of dystocia or stillbirth as a result of low calf viability (and often small calves) [see also the Proceedings from this meeting: Gustafsson et al., Stillbirths in Holstein heifers some results from Swedish research]. In cases of stillbirth and low calf viability the levels of both oestrone sulphate (see below) and PAG were low during late pregnancy and at the time of parturition. These findings suggest that since both hormones have a placental source of production, placental dysfunction could be a possible factor in low calf viability and stillbirth. Analyses of PAG should also be an important tool to monitor pregnancies in e.g. the mare.

The mare has also a very large production of relaxin from the utero-placental-foetal unit and the corpus luteum is not involved [32]. The production starts at around day 80, when the placenta begins major steroid synthesis. The secretion pattern is bimodal with a peak around day 150 , decline in the values and a second increase until parturition. The role of relaxin is not known, but most likely it supports the pregnancy in a synergistic way with progesterone/5 $\alpha$-pregnane. The assay of relaxin should be a very good indicator of foetal well-being, but unfortunately the assay is not operating any longer.

In the mare, a pronounced production of testosterone is seen [33]. The concentrations increase tenfold from the first month of pregnancy until a peak level at around 200 days. The levels decrease thereafter until parturition. The pattern of testosterone production is similar with the oestrogen production (see below). The first rise seems to be initiated by the production of eCG from the endometrial cups, but after 120 days of pregnancy the increase and decrease were related to the development and regression of the foetal gonads. The role of the testosterone during pregnancy in the mare is not known, but it is most likely related to an anabolic role during development of the foetus. It is also a known risk that pregnant mares with high testosterone values are considered to be "medicated" with testosterone.

Free oestrogens comprise several derivatives and the major biologically active substances are oestradiol-17 $\beta$, oestrone and oestriol. The aromatase enzyme plays the final role in production of oestradiol and oestrone from their precursor, androstenedione. During pregnancy, the foetal membranes play a major role in oestrogen secretion acting on the growth of the myometrium, synthesis of actomyosin and consequently an increase of the contractile capacity of the uterus. Additionally, oestrogen compounds at the end of pregnancy also work together with relaxin to soften the cervix and open the birth canal and stimulate the release of prostaglandin $\mathrm{F}_{2 \alpha}$ from the endometrium. In the cow, the levels in the maternal peripheral circulation start to increase between days 70 to 100 of gestation and reach a plateau from day 265 of pregnancy. During a few days before parturition, a larger amount of oestrogens appears in the blood circulation 
and declines rapidly to zero level postpartum. Most of the conjugated and non-conjugated forms of oestrogens are locally transformed within the foetal membranes. Placental oestrogens were also suggested for local regulatory factors [34], which control caruncular growth, differentiation and function. Oestrone sulphate, oestrone in its conjugated form, is the major oestrogen in maternal circulation. The levels of placental oestrogens by far exceed those of ovarian origin. Dobson et al.[35] suggested that oestrone sulphate might reflect placental viability and the measurement of oestrone sulphate might be a sensitive response variable indicative of conceptus functions. Oestrone sulphate has been shown to be a very important parameter to follow cows where the calf will be born dead [31]. The results indicate that deviating profiles of oestrone sulphate could be observed and the analyses of oestrone sulphate might be a part of monitoring foetal well-being. The levels of oestrone sulphate during late pregnancy and parturition and over 24 hours at 3 and 6 weeks prior to parturition were low in the dams carrying stillbirths due to small calves. These results indicate that the placental function for these calves was not the most optimal.

Oestrogen production in the mare involves several derivatives and the unique oestrogens - equilin and equilenin (the ring-B unsaturated oestrogens) - are formed in parallel with oestrone and oestradiol-17 $\beta$. They are to a very large extent conjugated. The production of oestrogens is the largest in comparison with other domestic species. It is easy to detect the excretion to the urine and the early methods detected large quantities in the urine already in 1930 by Zondek. The urine from pregnant mares can be extracted and purified to be used to help menopauseal women. One of the compounds is sold under the trade name Premarina and contains: oestrone, equilin and $17 \alpha-$ dihydroequilin; together with smaller amounts of $17 \alpha$ oestradiol, equilenin and $17 \alpha$-dihydroequilenin. The urine is collected from pregnant mares kept on so-called PMU-farms.

Smaller amounts of oestrogens are formed from the ovaries, but after day 80 the production is steadily increasing to reach a peak at around day 200; later on the levels flatten out and low levels are found at the time of parturition [36]. The patterns deviate somewhat dependent on which oestrogen derivative is measured. Since the oestrogen profiles are so dominating could they be used to separate between normal and impaired late pregnacies? Parkes et al.[37] have considered this possibility and followed mares with abnormal foetuses between 100 and 320 days. A decline in the levels indicates that the foetal well-being is not the best and that an increased risk for abortion is present. In a study by Madej et al.[38] mares were aborted with prostaglandin $\mathrm{F}_{2 \alpha}$ (twice daily) or combined treat- ment with oestradiol benzoate and oxytocin at about 150 days of pregnancy. The treatments triggered an endogenous prostaglandin production and the foetal membranes were separated with a sudden and pronounced drop in progesterone (or more likely $5 \alpha$-pregnane) levels. At the same time both oestrone sulphate and relaxin dropped. Thus it can be concluded that the placenta produces several hormones which can be used as biological markers of the status of the foetus.

Also in the porcine species at the second half of pregnancy large amounts of conjugated oestrogens, mainly oestrone sulphate, are found in the maternal circulation. In attempts to impair the pregnancies, cloprostenol or Gramnegative endotoxins were injected at day 80 of pregnancy [39]. Again oestrone sulphate showed to be an important parameter of foetal well-being and pregnancy outcome.

Circulating oestrogen concentrations in the bitch decreases during pregnancy period towards parturition and the origin seems to be the ovaries rather than the placenta [40-42]. Thus measurements of oestrogens could give very little information about the outcome of the pregnancy in the dog.

\section{References}

I. Fraenkel L: Die Funktion des Corpus luteum. Archiv Gynaekol (Munich) 1903, 68:438-443.

2. Slotta $\mathrm{KH}$, Ruschig $\mathrm{H}$, Fels E: Reindarstellung der hormone aus dem corpus luteum. Berich Dtsch Chem Geselischaft 1934, 67: 270.

3. Holtan DW, Ginther OJ, Estergreen VL: $5 \alpha$-pregnanes in pregnant mares. J Anim Sci 1975, 41:Abstract 450.

4. Fredriksson G: Release of prostaglandin $\mathbf{F}_{2 \alpha}$ during parturition and the postpartum period in the ewe. Theriogenology 1985, 24:33I-335.

5. Stewart DR, Kindahl H, Stabenfeldt GH, Hughes JP: Concentrations of 15-keto-13,14-dihydroprostaglandin $F_{2 \alpha}$ in the mare during spontaneous and oxytocin induced foaling. Equine Vet $J$ 1984, 16:270-274.

6. Fredriksson G, Buxton D, Uggla A, Kindahl H, Edqvist L-E: The effect of Toxoplasma gondii infection in unvaccinated and ISCOM-vaccinated pregnant ewes as monitored by plasma levels of 15 -ketodihydroprostaglandin- $F_{2 \alpha}$, progesterone, and oestrone sulphate. J Vet Med 1990, A 37:1 I3-122.

7. Kindahl $H$, Kornmatitsuk $B$, Gustafsson $H$ : The cow in endocrine focus before and after calving. Reprod Dom Anim 2004, 39:217-221.

8. Li Y, Perezgrovas R, Gazal OS, Schwabe C, Anderson LL: Antiprogesterone, RU 486, facilitates parturition in cattle. Endocrinology 199I, I 29:765-770.

9. Concannon PW, Yeager A, Frank D, lyampillai A: Termination of pregnancy and induction of premature luteolysis by the antiprogestagen, mifipristone, in dogs. I Reprod Fert 1990, 88:99-104.

10. Sankai T, Endo T, Kanayama K, Sakuma Y, Umezu M, Masaki J: Antiprogesterone compound, RU 486 administration to terminate pregnancy in dogs and cats. J Vet Med Sci I99I, 53:1069-1070.

II. Linde-Forsberg C, Kindahl H, Madej A: Termination of mid-term pregnancy in the dog with oral RU 486. J Small Anim Prac 1992, 33:331-336.

12. Baan M, Taverne MA, Kooistra HS, de Gier J, Dieleman SJ, Okkens AC: Induction of parturition in the bitch with the progesterone-receptor blocker aglepristone. Theriogenology 2005, 63:1958-1972. 
13. Granström E, Kindahl H: Species differences in circulating prostaglandin metabolites. Relevance for the assay of prostaglandin release. Biochim Biophys Acta 1982, 713:555-569.

14. Carlsson U, Fredriksson G, Alenius S, Kindahl H: Bovine virus diarrhoea virus, a cause of early pregnancy failure in the cow. J Vet Med A 1989, 36:15-23.

15. Carlsson U, Fredriksson G, Kindahl H, Alenius S: Effect of bovine virus diarrhoea virus on pregnancy in the ewe monitored by ultrasound scanning and levels of I5-keto-13,14-dihydroPGF $_{2 \alpha}$ and progesterone. Am J Reprod Immunol Microbiol 1987, | 4:91-98.

16. Fredriksson G, Kindahl H, Edqvist L-E: Endotoxin-induced prostaglandin release and corpus luteum function in goats. Anim Reprod Sci 1985, 8:109-121.

17. Daels PF, Starr M, Kindahl H, Fredriksson G, Hughes JP, Stabenfeldt $\mathrm{GH}$ : The effect of Salmonella typhimurium endotoxin on PGF$2 \alpha$ release and fetal death in the mare. J Reprod Fert 1987:485-492.

18. Odensvik K, Gustafsson H, Kindahl H: The effect on luteolysis by intensive oral administration of flunixin granules in heifers. Anim Reprod Sci 1998, 50:35-44.

19. Luthman J, Kindahl $\mathrm{H}$, Jacobsson SO: The influence of flunixin on the response to Salmonella typhimurium endotoxin in calves. Acta Vet Scand 1989, 30:295-300.

20. Daels PF, Stabenfeldt GH, Hughes JP, Odensvik K, Kindahl H: Effects of flunixin meglumine on endotoxin-induced prostaglandin $\mathbf{F}_{2 \alpha}$ secretion during early pregnancy in mares. Am J Vet Res |99|, 52:276-281.

21. Liggins GC, Fairclough RJ, Grieves SA, Kendell JZ, Knox BS: The mechanism of initiation of parturition in the ewe. Recent progress in hormonal research. 1973, 29:। II-I59.

22. Flower RJ, Rothwell NJ: Lipocortin-I: cellular mechanisms and clinical relevance. Trends Pharmacol Sci 1994, I 5:71-76.

23. Eissa HM, El-Belely MS: Sequential changes in plasma progesterone, total oestrogens and corticosteroids in the cow throughout pregnancy and around parturition. Br Vet J 1990, 1 46:24-29.

24. Patel OV, Takahashi T, Takenouchi N, Hirako M, Sasaki N, Domeki I: Peripheral cortisol levels throughout gestation in the cow: effect of stage of gestation and foetal number. Brit Vet J 1996, I 52:425-432.

25. Hydbring E, Madej A, MacDonald E, Drugge-Boholm G, Berglund B, Olsson K: Hormonal changes during parturition in heifers and goats are related to the phases and severity of labour. J Endocrinol 1996, 160:75-85.

26. Königsson K, Kask K, Gustafsson H, Kindahl H, Parvizi N: I5-Ketodihydro-PGF $\mathbf{F}_{2 \alpha}$, progesterone and cortisol profiles in heifers after induction of parturition by injection of dexamethasone. Acta Vet scand 2001, 42:15I-I59.

27. Xie S, Low RC, Nagel RJ, Kramer KK, Anthony RV, Zoli AP, Beckers JF, Roberts RM: Identification of the major pregnancy-specific antigens of cattle and sheep as inactive members of the aspartic proteinase family. PNAS I991, 88: 10247-I025I.

28. Panasiewicz G, Majewska M, Romanowska A, Dajnowiec J, Szafranska $B$ : Radiocompetition of secretory pregnancy-associated glycoproteins as chorionic ligands with luteal and uterine gonadotrophin receptors of pregnant pigs. Anim Reprod Sci in press. Jun I4 2006

29. Zoli AP, Guilbault LA, Delahaut P, Ortiz WB, Beckers JF: Radioimmunoassay of a bovine pregnancy-associated glycoprotein in serum: its application for pregnancy diagnosis. Biol Reprod 1992, 46:83-92.

30. Beckers JF, Drion PV, Garbayo JM, Perenyi Z, Zarrouk A, Sulon J, Remy B, Szenci O: Pregnancy associated glycoproteins in ruminants: inactive members of the aspartic proteinase family. Acta Vet Hung 1999, 47:46I-469.

31. Kornmatitsuk B, Dahl E, Ropstad E, Beckers JF, Gustafsson H, Kindahl $\mathrm{H}$ : Endocrine profiles, haematology and pregnancy outcomes of late pregnant Holstein dairy heifers sired by bulls giving a high or low incidence of stillbirth. Acta Vet Scand 2004, 45:47-68.

32. Stewart DR, Stabenfeldt GH: Relaxin activity in the pregnant mare. Biol Reprod 198I, 25:28I-289.

33. Silberzahn P, Zwain I, Martin B: Concentration increase of unbound testosterone in plasma of the mare throughout pregnancy. Endocrinology 1984, I | 5:416-419.
34. Hoffmann B, Schuler G: The bovine placenta; a source and target of steroid hormones: observations during the second half of gestation. Dom Anim Endocrinol 2002, 23:309-320.

35. Dobson H, Rowan TG, Kippax IS, Humblot P: Assessment of fetal number, and fetal and placental viability throughout pregnancy in cattle. Theriogenology 1993, 40:4I I-425.

36. Nett TM, Holtan DW, Estergreen VL: Plasma estrogens in pregnant and postpartum mares. J Anim Sci 1973, 37:962-970.

37. Parkes RD, Blackmore DJ, Rance TA, Park BK, Dean PDG: Plasma concentrations of equilin and oestrone in the assessment of feto-placental function in the mare. Vet $\operatorname{Rec} 1977,100: 511-512$.

38. Madej A, Kindahl H, Nydahl C, Edqvist L-E, Stewart DR: Hormonal changes associated with induced late abortions in the mare. J Reprod Fert 1987:479-484.

39. Cort $\mathrm{N}$, Kindahl $\mathrm{H}$ : The effect of a bacterial endotoxin or cloprostenol on the clinical status and hormonal levels in 80100 days pregnant gilts. Acta Vet Scand 1986, 27:|45-I58.

40. Hadley JC: Total unconjugated oestrogen and progesterone concentrations in peripheral blood during pregnancy in the dog. J Reprod Fert 1975, 44:453-460.

41. Hoffmann B, Hoveler R, Nohr B, Hasan SH: Investigations on hormonal changes around parturition in the dog and the occurrence of pregnancy-specific non conjugated oestrogens. Exp Clin Endocrinol 1994, 102:185-189.

42. Onclin K, Murphy B, Verstegen JP: Comparisons of estradiol, LH and FSH patterns in pregnant and nonpregnant beagle bitches. Theriogenology 2002, 57:1957-1972.
Publish with Biomed Central and every scientist can read your work free of charge

"BioMed Central will be the most significant development for disseminating the results of biomedical research in our lifetime. "

Sir Paul Nurse, Cancer Research UK

Your research papers will be:

- available free of charge to the entire biomedical community

- peer reviewed and published immediately upon acceptance

- cited in PubMed and archived on PubMed Central

- yours - you keep the copyright 